N. Fellouh ${ }^{1}$, M.L.Boukelloul' ${ }^{1}$, A. Aissi ${ }^{2}$, M. Fredj ${ }^{1}$
1 - Laboratory of Mineral Resources Valorization and Environment, Badji Mokhtar University, Annaba, Algeria, e-mail: nasrofellouh868@gmail.com

2 - Mining, Metallurgy and Materials Laboratory, National High School of Mining and Metallurgy, Annaba, Algeria

\title{
ASSESSMENT OF GEOTECHNICAL PROPERTIES OF DRAA EL MIZANE HIGHWAY TUNNEL (ALGERIA)
}

Purpose. To show the results of geotechnical studies and design the support system chosen in complex geological conditions especially in fault zones. The Draa El Mizane highway tunnel was a research site.

Methodology. The determination of geotechnical properties by different classification systems for the quality of the rock mass such as the $Q$ index, Rock Mass Rating RMR and the Geological Resistance Index GSI. In addition, the choice of the support system is validated by numerical modeling via the $2 \mathrm{D}$ Phase 2 program.

Findings. The geotechnical measures developed through extensometer monitoring show a major compatibility between the geotechnical design and the digital simulation, which validates the reliability of the selected support system.

Originality. A type of support chosen during construction is established, which corresponds to local specific conditions in order to eliminate instabilities.

Practical value. The values obtained by numerical modeling can give us a final decision for the support system chosen: values in terms of deformations - in order of $1.5 \mathrm{~cm}$ at the top, 7.5 and $13.5 \mathrm{~cm}$ for the left and right wings respectively, $9.0 \mathrm{and} 18 \mathrm{~cm}$ in the lower half left and right, $22.5 \mathrm{~cm}$ for the base of the tunnel. Furthermore, the results obtained by the measurements of instrumentation in the dimensioning of the support type are well illustrated through the measurements by an extensometer, which are very compatible with the results of numerical modeling.

Keywords: classification systems, geotechnical engineering, Phase2 2D, Fault zone, underground structures, Draa El Mizane highway tunnel

Introduction. The engineering in terms with underground structures in rocks which have weak geomechanical properties is often confronted with purely geotechnical subjects.

Just after the first step of the digging work, the initial state of the stresses around the intact rock changes causing excessive deformation and instability of the rock mass.

Among the greatest challenges regarding the prediction of the behavior in a type of material around the tunnel is the encounter of a fault zone [1]. Consequently, recognizing the impact of the geotechnical conditions and the influence of the geological constraints of the intact rock in a fault zone has become a design challenge which requires special analyses; this challenge has the main goal which is to find a support system adequate to the necessities of the constraints created during the mining works.

Nevertheless, there has been a major progression in designing stages for digging of underground excavations like tunnels. This design takes a safe and realistic evaluation using numerical studies on various series of geotechnical properties [2].

Furthermore, the digging technique plays a major role in maintaining the safety state of the tunnel works, hence the main role is to minimize the percentage of change in the terrestrial surface state at the top of the tunnel and reduce all displacements and excessive deformation generated by the area of influence on the perimeter, in this sense. The New Austrian Tunneling Method (NATM) has regularly been used for large diameter underground excavations, for example around-highway tunnels [3].

Furthermore, the disaster caused by an enormous distortion is related fundamentally to the lithology and the spatial design of the geological structure just as the geomechanical quality.

The ultimate objective of this work concerns the evaluation of the nature of the rock intact by certain classification systems. These systems are suitable for evaluation of the rock mass by the RMR, the $Q$ system and, finally, the GSI in real conditions.

In the following, local zones were investigated so as to propose the support for the structure requirements and subse-

(c) Fellouh N., Boukelloul M.L., Aissi A., Fredj M., 2020 quently validate their performing via the finite element method using Phase 2 2D software.

Location and geological investigation of the study area. The Draa El Mizane twin-tube tunnel is included in the project of the penetrant which links the province of Tizi Ouzou and the East-West Highway with a length of $950 \mathrm{~m}$ (Fig. 1), it is sited between the kilometer point KP $36+200$ and KP $37+150$.

The regional geological composition indicates the presence of a sedimentary rock mass type of Oligocene age and Miocene superior that are found in a combination named tectonic section of flysch, consequently they have a great influence from the point of view of tectonic deformation in this region [4].

The axes of the tunnel are extended in the mountain range in the region of Djurdjra Tel Atlas, this mountain range is of a great altitude, which reaches $2500 \mathrm{~m}$, formed by overlapping faults and reverse faults with an extension southward into the tectonic area of Kabyle. In reaction, the location of the tunnel is the consequence of the actions of the structural elements which constitute the Djurdjura massif and which are continuously in activity [5].

The overlapping and reverse types of rock mass, which are part of the structural elements, are observed at the site of the tunnel. In addition, and in parallel with the axis of the left tube, a very pleated structure that has low geomechanical characteristics is considered as a critical part in this work. This section is built up by a series of dense tectonics which renders the fault zone and gives way to important changes in the mode of the layer. In accordance with granulometry ranks, the sedimentary units of upper Oligocene-Miocene age are subdivided into three main sections: fault zone, M2 (sandstone-Argillite) and M3 (argillaceous limestone-marl) (Fig. 2). The fault zone is represented by rock pieces of distinct sizes, different positions on the emplacement of the tunnel, shattered and bent under the fact of a large distortion attached, interconnected but compressible and inflatable.

In hydrogeology, the site is characterized by units formed with alternating classic sediments. Since the levels of sandstone and pebbles being in a place between these units are permeable, the levels of argillites, clayey sandstones and marls are impermeable. No groundwater accumulates into the boreholes. 


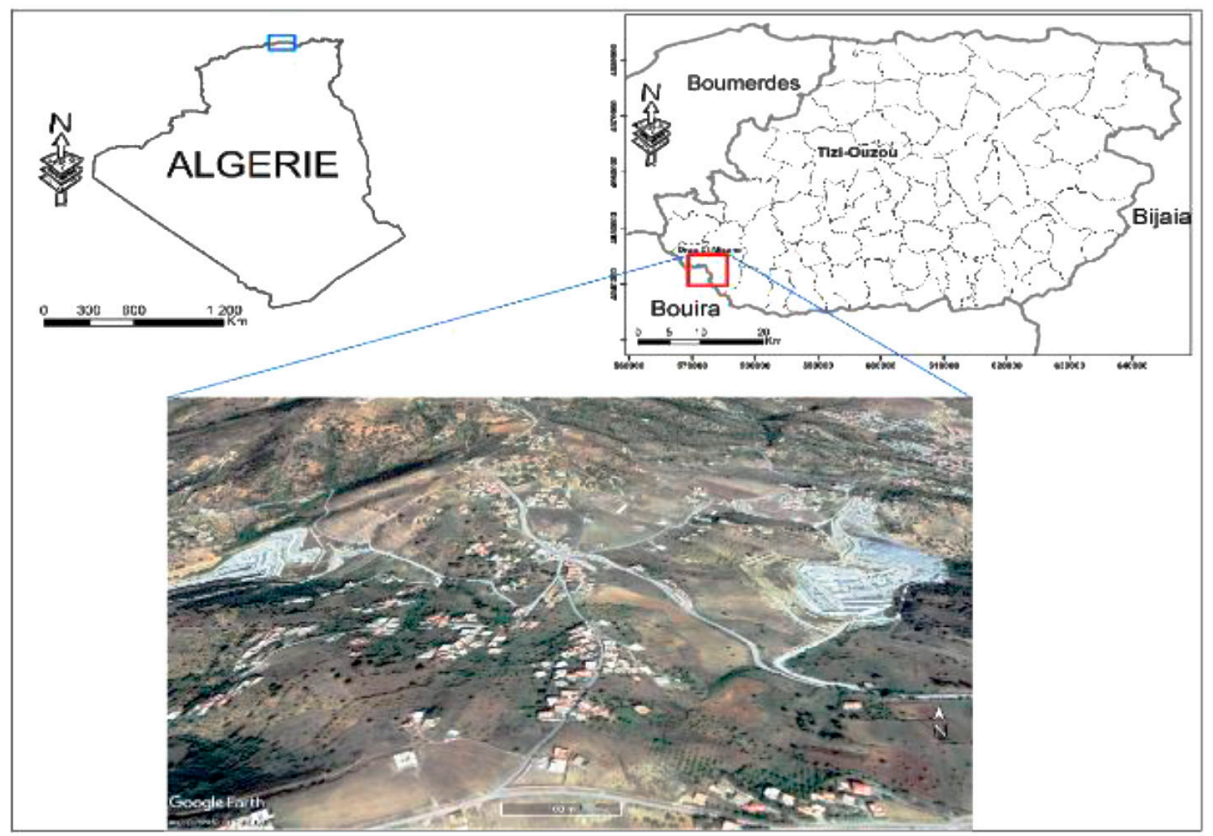

Fig. 1. Location of the study area

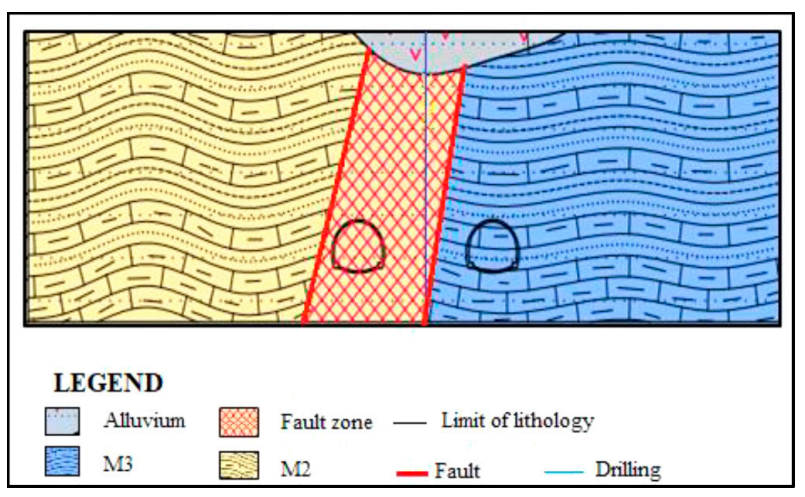

Fig. 2. Geological profile of the critical section

Characterization of geotechnical engineering of the surrounding rock. The horizontal plane of the tunnel coincides completely into a fault zone which is the exit portal in the meantime and kilometric point PK: $36+400$ of the left side tube, PK: $36+350-$ PK: $36+460$ of the right side tube. To reach a respectable understanding of the specificity of the rock mass in this part, core drilling and laboratory examinations were conducted for translating this quality geomechanically by certain classifications, for example: the Rock Mass rating RMR, the $\mathrm{Q}$ system and the Geological Strength Index GSI. The RMR categorization is a geomechanical classification for rock mass. It was demonstrated for the first time by Bieniawski in the South African Council for Scientific Research (CSIR) [6], based on variable experiences in digging underground structures. It takes into account sizes linked to the rock mass thereafter giving a valuation in the form of a total indication which appreciates its quality and then a conception of the construction project.

According to the Norwegian Geotechnical Establishment and based on the analyses of more than 200 underground excavations, Barton has developed a quality index (Q) which takes into consideration six parameters [7].

Both the Rock Mass Rating system and the Q system incorporate geological, geotechnical common features and design parameters to arrive at a quantitative value for the characterization of the site.
The GSI system was evolved by Hoek, et al. [8], the spatial circumstances of the healthy rock groups and their special characteristics are used to determine the deformability and tolerance of the rock mass.

In the present study, the overall rock assembly is of the flysch type, the GSI value of which is designated to take into consideration the criteria recommended by Marinos and Hoek [9].

The mechanical reaction of the rock mass after digging underground excavations is mainly represented by the static deformation module, which explains their use in various numerical analyses as a major character [10].

The quality of the rock mass was estimated using the solutions of the classification systems and using the correlations obtained by empirical relations. To find out the rock mass parameters along the critical area, certain class modes were used; the results are shown in Table 1.

Table 1

Geotechnical design parameters and rock mass classification for the critical section

\begin{tabular}{|c|c|c|c|c|}
\hline \multicolumn{2}{|c|}{ Geological unit } & $M_{2}$ & $\begin{array}{l}\text { Fault } \\
\text { zone }\end{array}$ & $M_{3}$ \\
\hline \multicolumn{2}{|c|}{$\begin{array}{l}\text { UCS, Uniaxial Compressive Strength } \\
\text { (Mpa) }\end{array}$} & 10 & 5 & 5 \\
\hline \multicolumn{2}{|c|}{$E_{i}$, Elasticity Modulus (MPa) } & 1500 & 80 & 1560 \\
\hline \multicolumn{2}{|c|}{ GSI, Geological strength Index } & 20 & 21 & 20 \\
\hline \multicolumn{2}{|c|}{$m_{i}$, material constant } & 17 & - & 7 \\
\hline \multicolumn{2}{|l|}{ v, Poisson's ratio } & 0.3 & 0.3 & 0.3 \\
\hline \multicolumn{2}{|c|}{$\gamma_{n}$, Unit weight $\left(\mathrm{kN} / \mathrm{m}^{3}\right)$} & 22 & 22 & 26 \\
\hline \multicolumn{2}{|c|}{$C$, Cohesion $(\mathrm{kPa})$} & 200 & 30 & 60 \\
\hline \multicolumn{2}{|c|}{$\theta$, Internal Friction angle $\left(^{\circ}\right)$} & 26 & 30 & 26 \\
\hline \multirow[t]{3}{*}{$\begin{array}{l}E_{m}, \text { Deformation } \\
\text { modulus, Mpa }\end{array}$} & $\begin{array}{l}\text { Nicholson and } \\
\text { Bieniawski }\end{array}$ & 93 & - & 82 \\
\hline & Hoek and Diederichs & 69 & - & 71 \\
\hline & Test pressure meter & 150 & 80 & 88 \\
\hline \multicolumn{2}{|c|}{$Q$, Tunneling Quality Index } & 0.066 & $0-0.07$ & 0.017 \\
\hline \multicolumn{2}{|c|}{$R M R$, Rock Mass Rating } & 26 & $0-20$ & 26 \\
\hline
\end{tabular}


Rock mass features such as Hoek-Brown constants, uniaxial compressive strength and the deformation modulus of the rock mass were determined using empirical equalizations based on the classification methods Q, GSI and RMR.

Among the empirical equations that have been established and the most mentioned by various researchers are those discussed and assessed based on their performance by Kayabasi and Gokceoglu [11].

In this approach, the value of deformation modulus of the rock mass is estimated by the equation of Nicholson and Bieniawski 1990 [12] and that of Hoek and Diederichs 2006 [13].

Provisional selected support system. The provisional support system is the main structure which ensures the original behavior of the rock mass during the digging of the tunnel. It is therefore advisable to examine successively the support system during construction and take into account different knowledge.

According to established classification practices, the support selected conforms to classes $C$ (Low rock) and $D$ (Very low rock) (Table 2).

Numerical modeling of retaining support system and studies performed by the phase $2 \mathrm{D}$ program. To better understand and appreciate the tunneling scenario, many designers are returning to numerical modeling. In addition, numerical analyzes can assess the issues of empirical methods to have optimally determined the support elements.

In this work, numerical modeling was executed with Phase 2 2D, a finite element program developed by Rocsience [14], it was used to find out the action of the rock mass to retain and preserve the safety of the various geotechnical works.

This program allowed us to take into consideration the dispersion of the loads between the digging phases and the relaxations of the surrounding rock to reflect well the criteria of the methodology of construction by NATM. Numerical analyses were conducted using the mechanism of the elastic-plastic solution.

In addition, $35 \mathrm{~cm}$ shotcrete, an HEB200B type steel coating and a $150 \times 150 \times 8 \mathrm{~m}$ thick wire mesh in 2 layers are seized in the rock class $D$ type. For the straight tube, the rock is type $C$, shotcrete $30 \mathrm{~cm}$, a coating of steel type HEB180B and a wire mesh $150 \times 150 \times 8 \mathrm{~m}$ thick in 2 layers.

These supports are also captured in linear composite to the model.

To achieve the installation of optimal support elements and especially in fault zone conditions, when digging the tunnel, the assessment must be made with necessary geotechnical measures like the extensometer measurement instrument and displacement gauges. Thereafter, certain modifications can be performed on the support mode based on the observation technique described in Eurocode 7 [15].

The computed design applied in the Phase 2 tests is presented in Fig. 3. Seven simulation phases are interpreted in the order of the construction stages and installation of the support elements for each tube.

According to Technical Manual For Design and Construction of Road Tunnels, the relaxation of the material handled in the weak rock masses in the new Austrian construction method is applied and reflected at $0.60(60 \%)$ in the excavations of the upper half, lower half and on the raft. For this, the properties of material are reduced to $60 \%$ at stage two and the support systems are installed at stage three [16]. To judge the results of a numerical simulation, field examinations were carried out in order to compare and validate the results.

Fig. 4 shows the installation of the Extensometer measurement system.

Discussion and Results. The deformations occurring into the surrounding rock, especially around the tunnel for each tube in the fault zone conditions, including the total displacements (Fig. 5), the collapse places and the Resis-

Provisional support chosen in the twin-tube tunnel according to the recommendation by classification system used

\begin{tabular}{|c|c|c|c|c|}
\hline \multirow{2}{*}{ Rock Mass type } & \multicolumn{2}{|c|}{ Low rock (class $C$ ) } & \multicolumn{2}{|c|}{ Very low rock (class $D$ ) } \\
\hline & Top & Middle & Top & Middle \\
\hline$R$, Tunnel radius (m) & \multicolumn{2}{|c|}{7.5} & \multicolumn{2}{|l|}{8} \\
\hline$P_{0}$, In-situ pressure $(\mathrm{MPa})$ & \multicolumn{2}{|c|}{1.17} & \multicolumn{2}{|l|}{2.64} \\
\hline ESR, Excavation Support Ratio & \multicolumn{2}{|c|}{$0.9-1.1$} & \multicolumn{2}{|c|}{$0.9-1.1$} \\
\hline Excavation/Provisional Support advance & \multicolumn{2}{|c|}{20 to $25 \mathrm{~m}$ maximum } & \multicolumn{2}{|c|}{ advancement of $2.0 \mathrm{~m}$ maximum } \\
\hline Steel retaining - Cinter & HEB 180 & HEB 220 & 5 to $10 \mathrm{~m}$ maximum & $1 \mathrm{~m}$ \\
\hline Shotcrete & \multicolumn{2}{|c|}{$30(\mathrm{C} 30-\mathrm{RN} 30)$} & \multicolumn{2}{|c|}{$35(\mathrm{C} 30-\mathrm{RN} 30)$} \\
\hline Rock bolt & \multicolumn{2}{|c|}{$(25 \mathrm{~mm})-\mathrm{SN}, 8-6-4 \mathrm{~m}(1 \times 1)$} & \multicolumn{2}{|c|}{$(32 \mathrm{~mm})$ IBO, $8-6-4 \mathrm{~m}(1 \times 1)$} \\
\hline Steel lattice & \multicolumn{2}{|c|}{$150 \times 150 \times 8$} & \multicolumn{2}{|c|}{$150 \times 150 \times 8$} \\
\hline pre-supporting iron bar-forepoling & \multicolumn{2}{|c|}{$45 \times(\varnothing 7.0, L=8 \mathrm{~m})$} & \multicolumn{2}{|c|}{$45 \times(\varnothing 7.0, L=8 \mathrm{~m})$} \\
\hline
\end{tabular}

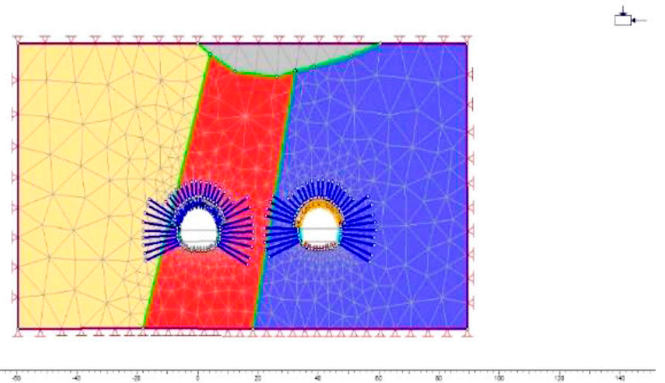

Fig. 3. Geometric model and generation of the mesh

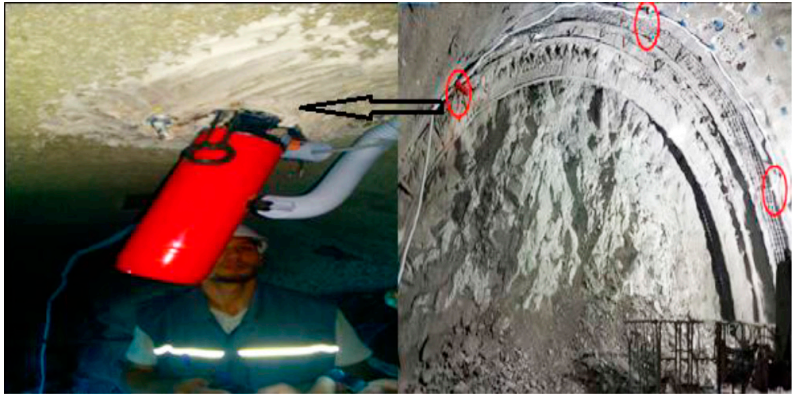

Fig. 4. Extensometer measurement system 


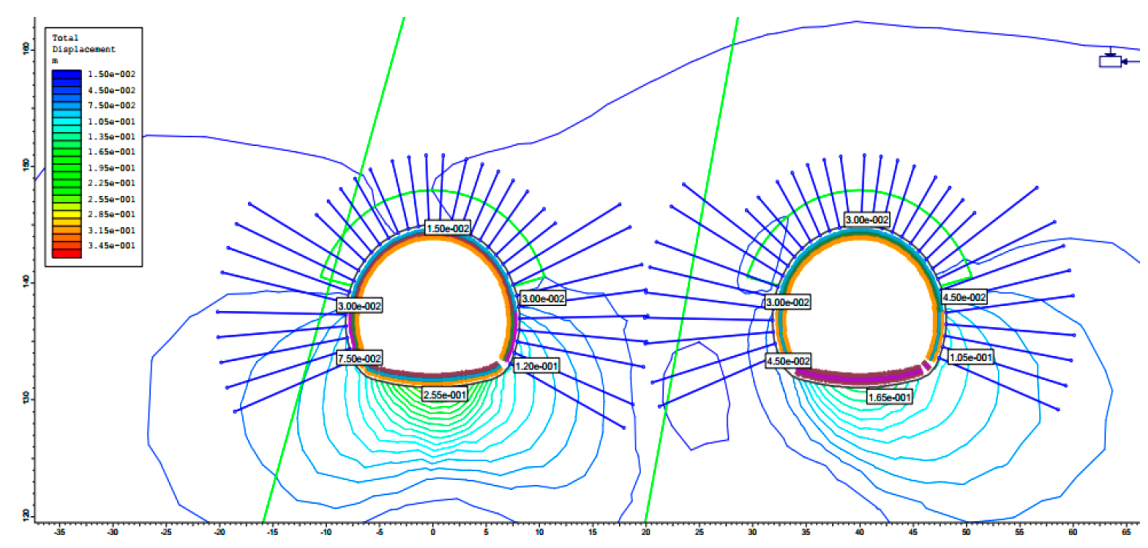

Fig. 5. Total displacements

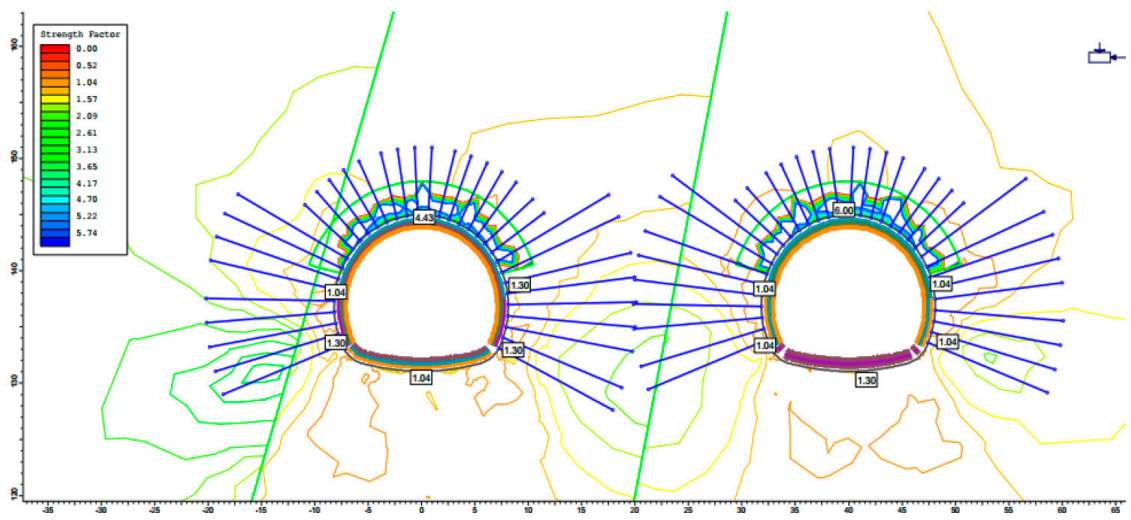

Fig. 6. Resistance factor

tance factors (Fig. 6) are determined. The two support classes are entered separately in this study. The results of the simulation of each type by Phase2 2D are illustrated in Table 3.

Examination of movements formed around the left side where the fault zone is encountered indicates a displacement of $1.5 \mathrm{~cm}$ in the top, 4.5 and $1.5 \mathrm{~cm}$ in the left and right wings, $6.0,1.5 \mathrm{~cm}$ in the left and right sides and the value of $4.5 \mathrm{~cm}$ from the base of the excavation.

In the right side, a displacement of $1.5 \mathrm{~cm}$ at the top of the tube, 7.5 and $13.5 \mathrm{~cm}$ in the left and right wings, 9.0 and $18.0 \mathrm{~cm}$ in the lower left and right halves and $22.5 \mathrm{on}$ the raft.

The adopted results indicate that the reinforcement by the anchor bolts and the umbrella vault allows increasing the adherence of the surrounding rock around the perimeter of the excavation, which implies a decrease in total displacements and an increase in the resistance coefficient.

In addition, due to examining the collapse zones of the tunnel peripheral it can be seen that the collapse is formed around the tunnel because the nature of the rock mass is low at the lower mass parameters.

The results of extensometer and deformation gauges provided in the table from the point of view of maximum deformations are naturally lower than those obtained by numerical modeling. Since the results of the classification systems are available, it will be more suitable to apply the extensometer carried out in a complex geology, including the existence of a fault zone.

The modeling of the main elements of the tunnel during construction is linked mainly by geological factors and an economic factor reflected by the selected support system which must be in accordance with the conditions of each site.

According to the results of numerical modeling and verification of instrumentation measures such as the extensometer for the class D support, it appears that the support proposed by the classification systems is able to withstand loads from the perimeter of the structure.

Table 3

Results of the Phase2 2D analysis and measurement of maximum deformations

\begin{tabular}{|c|c|c|c|c|c|}
\hline $\begin{array}{l}\text { Tunnel } \\
\text { ceiling }\end{array}$ & 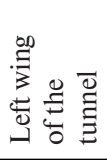 & 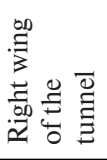 & 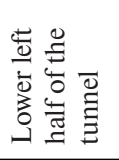 & 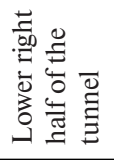 & $\begin{array}{l}\text { base of } \\
\text { tunnel }\end{array}$ \\
\hline \multicolumn{6}{|c|}{ Straight tunnel, Rock type $C$} \\
\hline \multicolumn{6}{|c|}{ Total deformation $(\mathrm{cm})$} \\
\hline 1.5 & 4.5 & 1.5 & 6 & 1.5 & 4.5 \\
\hline \multicolumn{6}{|c|}{ Resistance factor } \\
\hline 1.83 & 1.04 & 2.09 & 2.09 & 1.3 & 1.04 \\
\hline \multicolumn{6}{|c|}{ Collapse zones (\%) } \\
\hline 0 & 100 & 100 & 100 & 100 & 100 \\
\hline \multicolumn{6}{|c|}{ Left tunnel, Rock type $D$} \\
\hline \multicolumn{6}{|c|}{ Total deformation $(\mathrm{cm})$} \\
\hline 1.5 & 7.5 & 13.5 & 9 & 18 & 22.5 \\
\hline \multicolumn{6}{|c|}{ Resistance factor } \\
\hline 1.3 & 1.04 & 1.04 & 1.3 & 1.3 & 1.3 \\
\hline \multicolumn{6}{|c|}{ Collapse zones (\%) } \\
\hline 0 & 100 & 100 & 100 & 100 & 100 \\
\hline \multicolumn{6}{|c|}{$\begin{array}{l}\text { maximum strains obtained by measurement (extensometer or } \\
\text { strain gauges) }\end{array}$} \\
\hline 1.5 & 1.2 & 1.4 & 1.5 & 1.2 & - \\
\hline
\end{tabular}


Conclusion. Scientific and reasonable assessment of the rock mass is of vital importance in the choice of an adequate support system which must meet the strict construction requirements for underground structures such as tunnels.

The case study on the evaluation of geotechnical engineering on the Draa El Mizane site using empirical methods, in particular the evaluation of the rock mass in geomechanically weak formations and difficult to quantify such as fault zones.

To adapt the design of choosing support elements which satisfied the constraint created by the tunneling, numerical analyses of the construction taking into account the potential effect on the rock mass were carried out in order to assess and validate the suggested recommendations by the RMR, Q system and GSI classifications.

The results of the measurement system such as the extensometer and strain gauges have shown that there is a great compatibility between empirical conceptions and numerical analyzes.

Acknowledgement. The authors thank considerably all the engineers of the group YZGUN INSAAT, Tunnel department for having the data collection on the site. Also big thanks to all colleagues from the Mining Department, Faculty of Earth Sciences, Badji Mokhtar University.

\section{References.}

1. Kun, Mete (2015). The effect of shallow depth tunnelling on aboveground constructions. Arabian Journal of Geosciences, 8(7), 5247-5256. https://doi.org/10.1007/s12517-014-1507-7. 2. Marinos, V. (2019). A revised, geotechnical classification GSI system for tectonically disturbed heterogeneous rock masses, such as flysch. Bulletin of Engineering Geology and the Environment, 78(2), 899-912. https://doi.org/10.1007/s10064017-1151-Z.

3. Chen, J., Liu, W., Chen, L., Luo, Y., Li, Y., Gao, H., \& Zhong, D. (2020). Failure mechanisms and modes of tunnels in monoclinic and soft-hard interbedded rocks: a case study. KSCE Journal of Civil Engineering, 1-17. https://doi. org/10.1007/s12205-020-1324-3.

4. Arab, M., Rabineau, M., Déverchère, J., Bracene, R., Belhai, D., Roure, F., \& Sage, F. (2016). Tectonostratigraphic evolution of the eastern Algerian margin and basin from seismic data and onshore-offshore correlation. Marine and Petroleum Geology, 77, 1355-1375. https://doi.org/10.1016/j.marpetgeo.2016.08.021.

5. Aïdi, Ch., Beslierb, M.-O., Yelles-Chaouchea, A. K., Klingelhoeferc, F., Bracened, R., Galveb, A., Bounife, A., ..., \& Déverchèref, J. (2018). Deep structure of the continental margin and basin off Greater Kabylia, Algeria-New insights from wide-angle seismic data modeling and multichannel seismic interpretation. Tectonophysics, 728, 1-22. https://doi. org/10.1016/i.tecto.2018.01.007.

6. Kumar, R., Choudhury, D., \& Bhargava, K. (2016). Determination of blast-induced ground vibration equations for rocks using mechanical and geological properties. Journal of Rock Mechanics and Geotechnical Engineering, 8(3), 341-349. https://doi.org/10.1016/j.jrmge.2015.10.009.

7. Barton, N., \& Shen, B. (2017). Risk of shear failure and extensional failure around over-stressed excavations in brittle rock. Journal of Rock Mechanics and Geotechnical Engineering, 9(2), 210-225. https://doi.org/10.1016/j.jrmge.2016.11.004.

8. Hatzor, Y. H., He, B. G., \& Feng, X. T. (2017). Scaling rockburst hazard using the DDA and GSI methods. Tunnelling and Underground Space Technology, 70, 343-362. https://doi. org/10.1016/j.tust.2017.09.010.

9. Ren, Q., Wang, G., Li, M., \& Han, S. (2019). Prediction of rock compressive strength using machine learning algorithms based on spectrum analysis of geological hammer. Geotechnical and Geological Engineering, 37(1), 475-489. https://doi. org/10.1007/s10706-018-0624-6.

10. Fattahi, H., \& Moradi, A. (2018). A new approach for estimation of the rock mass deformation modulus: a rock engi- neering systems-based model. Bulletin of Engineering Geology and the Environment, 77(1), 363-374. https://doi.org/10.1007/ s10064-016-1000-5.

11. Kayabasi, A., \& Gokceoglu, C. (2018). Deformation Modulus of Rock Masses: An Assessment of the Existing Empirical Equations. Geotechnical and Geological Engineering, 36, 2683-2699. https://doi.org/10.1007/s10706-018-0491-1.

12. Bahaaddini, M., \& Moghadam, E. H. (2019). Evaluation of empirical approaches in estimating the deformation modulus of rock masses. Bulletin of Engineering Geology and the Environment, 78(5), 3493-3507. https://doi.org/10.1007/s10064018-1347-X.

13. Komu, M.P., Guney, U., Kilickaya, T.E., \& Gokceoglu, C. (2020). Using 3D Numerical Analysis for the Assessment of Tunnel-Landslide Relationship: Bahce-Nurdag Tunnel (South of Turkey). Geotechnical and Geological Engineering, 38(2), 1237-1254. https://doi.org/10.1007/s10706019-01084-9.

14. Kanik, M. (2019). Evaluation of the limitations of RMR89 system for preliminary support selection in weak rock class. Computers and Geotechnics, 115, 103159. https://doi. org/10.1016/j.compgeo.2019.103159.

15. Katsigiannis, G. (2017). Modern Geotechnical Codes of Practice and New Design Challenges Using Numerical Methods for Supported Excavations (Doctoral dissertation, UCL (University College London)). Retrieved from https://discovery.ucl. ac.uk/id/eprint/10037673.

16. Rehman, H., Naji, A.M., Ali, W., Junaid, M., Abdullah, R. A., \& Yoo, H. K. (2020). Numerical evaluation of new Austrian tunneling method excavation sequences: A case study. International Journal of Mining Science and Technology. https://doi.org/10.1016/j.ijmst.2020.03.009.

\section{Оцінка геотехнічних властивостей автомобільного тунелю Драа Ель Мізан (Алжир)}

\section{Н. Феллух ${ }^{1}$, М. Л. Букеллоул ${ }^{1}$, А. Аїссі ${ }^{2}$, М. Фредж ${ }^{1}$}

1 - Лабораторія валоризації гірничих ресурсів та навколишнього середовища, Університет Баджі Мохтар, м. Аннаба, Алжир, email: nasrofellouh868gmail.com 2 - Лабораторія гірничої справи, металургії та матеріалів, Національна вища школа гірничої справи та металургії, м. Аннаба, Алжир

Мета. Показати результати інженерно-геологічних досліджень і спроектувати опорну систему, обрану у складних геологічних умовах, особливо в зонах розломів. Місцем проведення спостережень був автодорожній тунель Драа Ель Мізан.

Методика. Визначення геотехнічних властивостей за допомогою різних систем класифікації якості гірської маси, таких як індекс Q, характеристика породної товщі (RMR) і індекс геологічної стійкості (GSI). Крім того, вибір опорної системи обгрунтований чисельним моделюванням за допомогою програми 2D Phase 2.

Результати. Геотехнічні заходи, розроблені на основі моніторингу за допомогою екстензометра, показують значну сумісність між геотехнічним проектуванням i цифровим моделюванням, що підтверджує надійність обраної опорної системи.

Наукова новизна. Встановлено тип опори, обраний під час будівництва, що відповідає місцевим специфічним умовам будівельного майданчика, щоб виключити нестабільність.

Практична значимість. Значення, отримані за допомогою чисельного моделювання, можуть дати нам остаточне рішення для обраної опорної системи: значення щодо деформацій - близько 1,5 см у верхній частині, 7,5 
і 13,5 см для лівого та правого крил відповідно, 9,0 і 18 см у нижній половині зліва та справа, 22,5 см в основі тунелю. Крім того, результати, отримані при вимірюванні за допомогою контрольно-вимірювальної апаратури при визначенні розмірів типу опори, добре ілюструються вимірами екстензометра, що збігаються з результатами чисельного моделювання.

Ключові слова: класифікаційні системи, інженерна геологія, програма Phase 2 2D, зона розломів, підземні споруди, автодорожній тунель Драа Ель Мізан

\section{Оценка геотехнических свойств автомобильного тоннеля Драа Эль Мизан (Алжир)}

\section{Н. Феллух ${ }^{1}$, М.Л. Букеллоул ${ }^{1}$, А. Айсси ${ }^{2}$, М. Фредж⿻ ${ }^{1}$}

1 - Лаборатория валоризации горных ресурсов и окружающей среды, Университет Баджи Мохтар, г. Аннаба, Алжир, email: nasrofellouh868@gmail.com

2 - Лаборатория горного дела, металлургии и материалов, Национальная высшая школа горного дела и металлургии, г. Аннаба, Алжир

Цель. Показать результаты инженерно-геологических исследований и спроектировать опорную систему, выбранную в сложных геологических условиях, особенно в зонах разломов. Местом проведения наблюдений был автодорожный тоннель Драа Эль Мизан.

Методика. Определение геотехнических свойств с помощью различных систем классификации качества горной массы, таких как индекс Q, характеристика породной толщи (RMR) и индекс геологической устойчивости (GSI). Кроме того, выбор опорной системы обоснован численным моделированием с помощью программы 2D Phase 2.

Результаты. Геотехнические меры, разработанные на основе мониторинга с помощью экстензометра, показывают значительную совместимость между геотехническим проектированием и цифровым моделированием, что подтверждает надежность выбранной опорной системы.

Научная новизна. Установлен тип опоры, выбранный во время строительства, который соответствует местным специфическим условиям строительной площадки, чтобы исключить нестабильность.

Практическая значимость. Значения, полученные с помощью численного моделирования, могут дать нам окончательное решение для выбранной опорной системы: значения касательно деформаций - порядка 1,5 см в верхней части, 7,5 и 13,5 см для левого и правого крыльев соответственно, 9,0 и 18 см в нижней половине слева и справа, 22,5 см в основании тоннеля. Кроме того, результаты, полученные при измерении с помощью контрольно-измерительной аппаратуры при определении размеров типа опоры, хорошо иллюстрируются измерениями экстензометром, которые совпадают с результатами численного моделирования.

Ключевые слова: классификационные системы, инженерная геология, программа Phase $2 \mathrm{D}$, зона разломов, подземные сооружения, автодорожсный тоннель Драа Эль Мизан

Recommended for publication by Dr. S. Ranrli. The manuscript was submitted 28.04.20. 